\title{
BCL6 Gene
}

National Cancer Institute

\section{Source}

National Cancer Institute. BCL6 Gene. NCI Thesaurus. Code C24260.

This gene is involved in transcriptional repression and plays a role in the modulation of Bcell responses. 